\title{
Modelling the Non-Linear Energy Intensity Effect Based on a Quantile-on-Quantile Approach: The Case of Textiles Manufacturing in Asian Countries
}

\author{
Muhammad Haseeb ${ }^{1}{ }^{(}$, Sebastian Kot ${ }^{2,3}, * \mathbb{C}$, Hafezali Iqbal Hussain ${ }^{1,4}(\mathbb{D}$, \\ Leonardus WW Mihardjo ${ }^{5}$ and Piotr Saługa ${ }^{6}$ \\ 1 Taylor's Business School, Taylor's University Lakeside Campus, 1 Jalan Taylors, Subang Jaya 47500, Malaysia; \\ muhammad.haseeb@taylors.edu.my (M.H.); hafezali.iqbalhussain@taylors.edu.my (H.I.H.) \\ 2 Faculty of Economic and Management Sciences, North-West University, Vaal Triangle Campus, \\ P.O. Box 1174, Vanderbijlpark 1900, South Africa \\ 3 The Management Faculty, Czestochowa University of Technology, 42-201 Czestochowa, Poland \\ 4 University of Economics and Human Sciences in Warsaw, Okopowa 59, 01-043 Warsaw, Poland \\ 5 School of Business Management, Bina Nusantara University, Jalan Hang Lekir I, no. 6, Senayan, \\ Jakarta 10270, Indonesia; mihardjo@gmail.com \\ 6 Department of Management, Faculty of Applied Sciences, WSB University, \\ 41-300 Dąbrowa Górnicza, Poland; psaluga@wsb.edu.pl \\ * Correspondence: sebacat@zim.pcz.czest.pl; Tel.: +48-34-3250-345
}

Received: 10 March 2020; Accepted: 26 April 2020; Published: 3 May 2020 updates

\begin{abstract}
The objective of the current examination is to identify the dynamic relationship between the textile industry and energy intensity. The study evaluates the asymmetric impact of textile manufacturing on energy intensity in leading Asian economies based on textile dominance. China, Indonesia, India, Pakistan, Bangladesh, Malaysia, South Korea, Thailand, Japan and Vietnam are dominant in textile manufacturing. In the present study we used yearly textiles and clothing data from top ten selected Asian textile manufacturing countries from 1990 to 2018. The results of quantile-on-quantile regression $(\mathrm{QQ})$ confirmed that textiles and clothing $(\mathrm{T} \& \mathrm{C})$ production have a positive and significant impact on energy intensity in all countries. The results further suggested that a low level of T\&C production increases the level of energy intensity in all selected countries. On the other hand, the results of Granger causality in quantiles confirm a bidirectional causal relationship between $T \& C$ production and energy intensity in all selected countries except Thailand and Japan, where a uni-directional causal connection between textile and clothing manufacturing and energy intensity can also be found. This study recommends that governments and investors need to invest more in green and advanced technologies to reduce the energy intensity in Asian economies.
\end{abstract}

Keywords: non-linear model; energy intensity; Asian countries; quantile-on-quantile

\section{Introduction}

Industrialization has a positive impact on several economic indicators and is an important factor in the growth of many countries. Benefits of industrial development include job creation, augmented trade, increased economy of scale and technological progress [1]. Since the start of the First Industrial Revolution, the textile industry has been considered an important part of world economy. This industry has historical roots dating back to $3000 \mathrm{BC}[2,3]$. The prominence of the textile industry is notable for generating foreign exchange through trade expansion, particularly in emerging economies [3]. In many Asian countries, textile sector is considered as a backbone for creating employment opportunities for both men and women [3-6]. 
However, from an environmental perspective, industrial growth is notable for adversely influencing climate conditions [7-9]. Many investigations have highlighted the growing problems due to environmental degradation. In recent years, climate vulnerability has been recognized as an international issue, since it is responsible for carrying numerous harmful effects on a country's growth and the prospect of sustainability $[10,11]$. The extensive usage of energy and resources (water, minerals, etc.) in various industries has augmented the problems linked to environmental quality and poses a severe threat to environmental sustainability. The rapid degradation of climate conditions is linked to increased industrialization, augmented energy intensity (ENI) and the burning of fossil fuels [12]. In a similar context, many recent studies have raised environmental concerns about the growth of the textile industry [13-16]. In this regard, Yan et al. (2016) [17], while analyzing the environmental impacts, argued that energy utilization is the barricade for the notion of sustainability in the textile industry. Given concerns for the significant water usage in fabric dyeing, Nimkar (2018) [18] stated that the increased utilization of supercritical carbon dioxide has solved the issue of effluent expulsion into the environment. However, the process has increased the industrial reliance on power due to this process being energy-intensive. Similarly, Huang, et al. [2] also established that the textile manufacturing process of weaving, spinning and wetting is highly energy-intensive, and leads to an increasing environmental burden.

In line with the above, the purpose of the present investigation is to identify the dynamic relationship between the textile industry and energy utilization. We evaluate the asymmetric impact of textile manufacturing on energy intensity in leading Asian economies based on the dominance of their textile industries in a global context. The major textile manufacturing countries in Asia are China, Indonesia, India, Pakistan, Bangladesh, Malaysia, South Korea, Thailand, Japan and Vietnam. Empirical investigations in several studies in the current literature have adopted traditional statistical methods while examining crucial relationships [19-22]. In this regard, Sharif, Afshan and Qureshi (2019) [23] asserted that the use of conventional econometrics may lead to biasness and produce unreliable results, and that more-advanced methods are needed to examine the relationship between crucial variables to strengthen the reliability of outcomes.

Considering the above matters, the current study has adopted a novel quantile-on-quantile (Q-Q) approach developed by Sim and Zhao (2015) [24] to examine the critical association between textile manufacturing and energy intensity (a measure of the energy inefficiency of an economy) in the selected economies. Our adopted methodology recognizes the non-linear relationship between the variables of interest in numerous lower, middle and upper quantiles of both dependent and independent variable. Although the stage of economic development varies in selected nations, the novelty of the Q-Q approach lies in being able to examine the impact of low, medium and high levels of textile development on variant low, medium and high levels of energy intensities in a given economy using the bivariate method of association. In this way, the Q-Q methodology is able to capture the influence of the country-specific textile industry growth on varying energy trends in the Asian nations separately. Hence, the current study can offer fresh insights on a matter of international concern: the increasing energy dependence of national industries. Focusing on the textile and garment manufacturing sector across the Asian region, we achieve this objective using a detailed analysis of several quantiles that portray relationships at different stages of the growth of the variables.

The rest of the article is outlined as follows: Section two presents the existing studies on the textile-environment nexus, with a focus on carbon emissions and energy consumption. Section three briefly discusses the methodology. The empirical outcomes and their interpretations are explained in section four. At the end, section five provides the conclusion of the study, along with its policy implications.

\section{Literature Review}

Given the significance of sustainability in modern business, many studies have investigated the impact of business and industrial practices on environmental conditions [25-28]. In this context, many studies are focused on identifying energy efficiency solutions [29-31]. In this regard the role of energy intensity has 
been investigated in several economic sectors, including transportation [32-34], manufacturing [35-37], development [38,39], information and communication [40,41], agriculture [42,43], etc. Considering the constant demand for textiles and clothing, as well as the significant impact of the textile industry on economic growth in many countries, empirical evaluation of the contribution of the textile industry to growth, and its growing environmental impact, have been identified in several studies [13,44], particularly for developing economies [14,45-47]. Among them, You, Cheng and Yan (2009) [48] examined the role of the textile industry and its environmental impact in China. The authors analyzed Chinese textile industry data from 1990 to 2006. Their study established that textile and clothing production is positively related to the country's economic growth; however, it has negatively influenced environmental conditions, thereby posing a threat to the sustainable development of the Chinese economy. Similarly, elaborating the ecological concerns in the textile sector industry of India, Chavan (2001) [49] found a negative impact of the textile industry due to the lack of environmental regulations, energy dependence and increased pollution, especially in textile wet processing operations. Martínez (2010) [50] also investigated the role of energy in the textile industries of Colombia and Germany between 1998 and 2005. This study found that the manufacturing of textiles is directly linked to energy utilization. The increase in production resulted in increased energy usage in both countries, putting higher pressure on the environment. The study further concluded that in order to bring about efficiency in energy usage, the textile industry in Germany relies on process transformation and the price of energy. Energy efficiency in the textile industry of Colombia is attained through alteration of manufacturing procedures, research and development investment, and technological advancements.

Moreover, Li et al. (2011) [51] investigated carbon dioxide utilization in the production of black garments. The study reported that material processing produces highest toxic emission i.e., fifty-six percent. The investigation also found that emission from waste-water and energy usage account for the second highest emissions, i.e., thirty-four percent of $\mathrm{CO}_{2}$ discharge. These thus account for $90 \%$ of emissions. Similar results are reported in the examination of Wang and $\mathrm{Xu}$ (2011) [52] that stated that a significant portion of $\mathrm{CO}_{2}$ discharge of China is from the textile manufacturing industry. Likewise, Yan et al., (2016) [17] analyzed carbon emissions in the textile industry of China. They found power usage (electricity and thermal power) to be significant reasons for the increased carbon discharge of the textile industry. Wang et al. (2015) [53] studied $\mathrm{CO}_{2}$ discharges in the Chinese textile industry. The study reported that energy efficiency and economy of scales with technological improvements are improving emission levels in the textile sector, resulting in decreased emission levels.

Sitompul and Owen (2005) [54] examined the Indonesian textile industries that contribute significantly to $\mathrm{CO}_{2}$ discharge and power consumption. For this study, the authors utilized data from 1980-2000. They found that economic growth is the highest contributing factor underlying increased $\mathrm{CO}_{2}$ discharge, particularly from the textile sector of Indonesia, along with the chemical and paper industries. In Iran, Hasanbeigi et al. (2012) [55] inspected the environmental impact of the textile industry. The authors focused on five prominent sub-sectors of the textile industry. The results showed that power utilization is the leading cause of environmental damage in the spinning sub-sector of the textile industry. In the worsted fabric wet-processing, manufacturing, carpet production and weaving sub-sectors, the authors found thermal power to be the significant detrimental factor contributing to environmental degradation. Reddy and Ray (2010) [56] studied factors contributing to environmental degradation in the textile industry of India using data from 1992 to 2005 . They found that $16 \%$ of power consumption in the Indian economy is attributable to the textile industry. Moreover, the authors stated that the textile industry contributes highest in terms of $\mathrm{CO}_{2}$ discharge with emission levels increasing by $800 \%$ percent in the studied period.

Zabaniotou and Andreou (2010) [57] examined increasing GHG emissions in the textile industry of Greece. They reported that use of cotton fiber is a useful way to decrease emissions in the textile industry. In addition, the authors found that cotton ginning waste could be a solution to energy substitution and improve GHG emanation in the textile industry of Greece. Priambodo and Kumar (2001) [58] analyzed carbon discharge and energy efficiency in Indonesian industries. The authors 
studied 73 small and medium industries (SMI). In terms of fuel usage, the study revealed that the textile industry plays a dominant part of national energy use. Likewise, the study also found that textile SMIs contribute the highest carbon emissions in the Indonesian economy.

In another study, Bevilacqua et al., (2010) [59] examined the contribution of South African textile industries to ecological deterioration. In doing so, the study focused on the supply-chain of textile industries in the country. Power usage was the prime cause of augmented $\mathrm{CO}_{2}$ discharge in the textile related supply-chain. The study found that the increase in electricity consumption and thermal energy resulted in increased greenhouse gas emissions. Hong et al., (2010) [60] analyzed the association of the textile industry in Taiwan with ecological degradation. For this, the authors investigated the role of energy in 303 businesses in Taiwan. In particular, the study focused on the impact of energy saving in the studied businesses associated with the textile industry. The study reported that power saving has resulted in declining emission levels to 143,669 tons, highlighting the dominant role of energy usage in the textile enterprises of Taiwan.

Likewise, Ma and $\mathrm{Lu}$ (2015) [16] examined the factors contributing to environmental degradation in the textile industry of China. They reported that economic growth is a vital factor in increased $\mathrm{CO}_{2}$ emissions in China. Similarly, the study found that energy intensity plays a vital part in reducing $\mathrm{CO}_{2}$ discharge in the Chinese textile industry. Lin and Maubarak (2013) [61] concluded that energy use is the vital contributor to carbon discharge in the textile industry of China between 1986 and 2010. In recent literature, Huang et al., (2017) [2] also reported that coal consumption is the main reason for deteriorating environmental conditions associated with the Chinese textile industry. Similar to Ma and Lu (2015) [16], the authors found that energy intensity plays a significant role in the Chinese textile industry.

Ganesan et al. (2015) [15] examined the role of energy and carbon discharge in the Indian textile industry in more recent years. Unlike Reddy and Ray (2010) for observation in the 90's [56], the outcome of the study stated that energy usage in the Indian textile industry is reduced by almost six percent. A similar trend is exhibited in $\mathrm{CO}_{2}$ discharge patterns and reduced by eight percent. Based on their findings, the authors suggested that the measures of environmental quality are improving in Indian textile industries in terms of energy intensity and carbon emissions. Lin and Ahmad (2017) [62] investigated the factors contributing to environmental degradation in Pakistan. The study employed data from 1990 to 2014. They found that an increase in population gives rise to environmental degradation in the country. Moreover, growth of the economy also played a dominant part in enhancing emissions, particularly in the textile industry. The authors further found mixed results in terms of energy use intensity, stating that the level of energy usage is dependent on factors such as energy price, process efficiency, etc. resulting in heterogeneous findings in decomposed series.

Focusing on power utilization, Palamutcu (2010) [63] analyzed the energy structure in the Turkish textile industry. The author emphasized the power consumption in the processing stage of cotton. The study reported increased utilization of energy for cotton processing in the Turkish textile industry. The study found that actual utilization of energy in processing is much larger than the anticipated power usage, and therefore should be controlled for having an adverse environmental impact. Similarly, Thai, Tokai and Nguyen (2011) [64] studied the notion of sustainability in the textile industry of Vietnam. The study focusses on an eco-labeling perspective in the apparel industry, while highlighting the presence of ecological threats during the production process of textile and clothing. Particularly, the study stated that wet processing is the largest pollution source, water- and energy-intensive process, contributing 76 percent to total water and 56 percent to total energy usage, and it stresses the need for environmental adaption in textile industry.

\section{Methodology}

This section explains the quantile-on-quantile (QQ) approach, which generally involves comparison amongst two probability distributions by plotting their quantiles against each other (Sim and Zhou, 2015) [24]. Recently researchers looked at the QQ method in a generic sense, and 
believe it to be method developed from a combination of quantile regression and non-parametric estimation. Further, this section sheds light on the relationship between the variables of the study, i.e., textile and clothing manufacturing and energy intensity. The quantile regression methodology was widely acknowledged by the researchers after it was developed and shared in the seminal work of Koenker and Bassett (1978) [65]. This approach was seen as an advancement of the classical linear regression model. The unique feature that differentiates quantile regression analysis from ordinary least square (OLS) estimation is its ability to analyze the detailed impact of the independent variable on dependent variable, i.e., it examines the center as well as the tail part of the dependent variable distribution. In addition, the feature of local linear regression also differentiates quantile regression from OLS estimation as it details the local effect. The quantiles of an independent variable is use to examine the effect on the dependent variable. This study examines the impact of textile and clothing production on the energy use intensity of a country, and will be carried out by checking the quantile effect of textile production on quantile effect of energy intensity of the country. In this context the quantile regression model for the study is:

$$
\mathrm{EIN}_{\mathrm{t}}=\gamma^{\mathrm{w}}\left(\mathrm{T} \& \mathrm{C}_{\mathrm{t}}\right)+\varepsilon_{\mathrm{t}}^{\omega}
$$

where, $\mathrm{EIN}_{\mathrm{t}}$ stands for the energy intensity, i.e., adjusted energy intensity of a country for all the changes in the energy price of a country in a period denoted by $t$. In the same way, the variable $T \& C_{t}$ explains the growth rate of the textile production activities in a specific country in a period t. The term $\omega$ refers to the quantile of the conditional distribution of the energy intensity, which in this model is $\mathrm{EIN}_{\mathrm{t}}$. Further, the model also takes into consideration the error term, i.e., $\varepsilon_{\mathrm{t}}$ which in this specific model is zero (conditional $\omega$ th quantile). Further, the relevant information regarding the link between the textile production and energy intensity was not known; hence $\gamma$ was also incorporated into the model as an unknown function.

In order to use nonparametric estimation techniques, several elements are of critical importance, such as bandwidth choice. The main reason for its criticality lies in its feature of identifying the neighborhood size around the target point, which ensures the smoothness of estimates. Apart from this, the justification for the choice of bandwidth is dependent on creating an equilibrium between bias and variance that are the results of large and small bandwidth. In this study, the experience of Sim and Zhou (2015) [24] was borrowed and that is why we used bandwidth parameter of 0.05 .

\section{Data Analysis and Interpretation}

In this research, the authors have used the yearly data of textiles and clothing (T\&C) (as the percentage of manufacturing value-added) and energy intensity level of primary energy (as the megajoule per GDP purchasing power parity (PPP)) as an intermediary for energy inefficiency of the top ten Asian textile manufacturing countries selected. Additionally, the present research used the yearly data from the period of 1990 to 2018. The information was changed into quarterly from yearly perception using a quadratic match approach. This methodology is refreshing when the data is changed from low period to high period since it adjusts the regular and end-to-end varieties in the data period. The quadratic match-sum method was applied in different past examinations $[23,66]$. All the data was gathered by the World Development Indicator (WDI) administered by the World Bank [67]. The final data was utilized in the form of normal logarithmic series to give vigorous and comparable results. 
The discoveries of descriptive measurements are clarified in Table 1 . The mean for energy intensity and $T \& C$ manufacturing is positive in all countries. The highest mean figure for energy intensity is for South Korea (7.421), followed by India (6.548) and Vietnam (6.151). On the other hand, the lowest value for energy intensity is China (3.172), followed by Bangladesh (3.544) and Indonesia (4.584). The middle values for energy intensity are Malaysia (5.295), Pakistan (5.187) and Thailand (5.186). The mean value of energy intensity for Japan is 4.869. Opposingly, the highest value for T\&C manufacturing is in the case of Bangladesh (38.385\%) followed by Pakistan (29.224\%) and Vietnam (17.512\%). The lowest values are Japan $(2.850 \%)$, Malaysia $(3.480 \%)$ and South Korea $(7.173 \%)$. The medium average values are Indonesia (14.108\%), China (11.118\%), Thailand (10.892) and India (10.499\%). Moreover, the outcomes of Jarque-Bera (JB) measurements are also used to check the normality of the factors for all nations. The results of JB tests demonstrated non-normal distribution for T\&C and energy intensity in all nations indicating a solid presence of non-linearity in the every one of the nations, which propels us to apply distinctive quantile analyses, given the ability of the method to identify structural breaks whilst accounting for asymmetric and nonlinearity in the relationship amongst variables $[68,69]$.

Table 1. Results of descriptive statistics.

\begin{tabular}{|c|c|c|c|c|c|c|}
\hline Countries & Mean & Min. & Max. & Std. Dev. & JB Test & $P$-Value \\
\hline \multicolumn{7}{|c|}{ Panel A: Energy Intensity } \\
\hline China & 3.172 & 0.426 & 4.462 & 0.321 & 14.821 & 0.000 \\
\hline India & 6.548 & 4.731 & 8.548 & 1.224 & 20.882 & 0.000 \\
\hline Pakistan & 5.187 & 4.422 & 5.626 & 0.361 & 30.617 & 0.000 \\
\hline Bangladesh & 3.544 & 3.129 & 3.901 & 0.225 & 13.270 & 0.000 \\
\hline Malaysia & 5.295 & 4.682 & 5.773 & 0.304 & 18.051 & 0.000 \\
\hline Indonesia & 4.584 & 3.525 & 5.306 & 0.513 & 18.244 & 0.000 \\
\hline Thailand & 5.186 & 4.485 & 5.648 & 0.354 & 34.666 & 0.000 \\
\hline Vietnam & 6.151 & 5.619 & 7.548 & 0.486 & 13.845 & 0.001 \\
\hline Korea & 7.421 & 6.548 & 8.348 & 0.569 & 22.872 & 0.000 \\
\hline Japan & 4.869 & 3.742 & 5.325 & 0.445 & 6.247 & 0.044 \\
\hline \multicolumn{7}{|c|}{ Panel B: Textile and Clothing Manufacturing } \\
\hline China & 11.183 & 9.975 & 14.793 & 1.393 & 14.969 & 0.000 \\
\hline India & 10.499 & 7.193 & 15.474 & 2.434 & 23.029 & 0.000 \\
\hline Pakistan & 29.244 & 26.129 & 33.329 & 2.786 & 37.453 & 0.000 \\
\hline Bangladesh & 38.385 & 19.798 & 51.043 & 9.556 & 91.320 & 0.000 \\
\hline Malaysia & 3.480 & 1.552 & 6.485 & 1.637 & 26.247 & 0.000 \\
\hline Indonesia & 14.108 & 9.786 & 21.339 & 3.549 & 24.445 & 0.000 \\
\hline Thailand & 10.892 & 6.448 & 29.664 & 5.349 & 36.566 & 0.000 \\
\hline Vietnam & 17.512 & 9.812 & 21.828 & 3.935 & 16.732 & 0.000 \\
\hline Korea & 7.173 & 3.463 & 13.816 & 3.499 & 26.423 & 0.000 \\
\hline Japan & 2.850 & 1.585 & 4.744 & 1.144 & 28.310 & 0.000 \\
\hline \multicolumn{7}{|c|}{ Source: authors' estimates } \\
\hline
\end{tabular}

Moreover, the authors of the present study have investigated the association between energy intensity and textile and attire manufacturing in all selected top Asian nations. The discoveries of the correlations estimation are reported in Table 2. The coefficient of association for all countries is significant at the $1 \%$ level, indicating a positive connection between T\&C manufacturing and energy intensity in all selected countries. The highest coefficient is found in Bangladesh (0.981) trailed by 
Pakistan (0.958) and China (0.945). The lowest estimation of correlation is found by in South Korea (0.875), Japan (0.853) and Malaysia (0.856). The middle value of the coefficient of correlation is found in the case of Indonesia (0.924), India (0.917), Vietnam (0.893) and Thailand (0.883). Moreover, the t-stats and significance values affirm the importance of the connection between energy intensity and T\&C manufacturing. The discoveries of a relationship affirms a positive association between both variables in every single Asian nation, which suggests that $T \& C$ manufacturing is one of the wellsprings of energy consumption in Asian nations.

Table 2. Results of correlation between (textiles and clothing) $T \& C$ and augmented energy intensity (ENI).

\begin{tabular}{cccc}
\hline Country & Correlation & t-Statistics & $P$-Value \\
\hline China & 0.945 & 8.382 & 0.000 \\
\hline India & 0.917 & 6.968 & 0.000 \\
\hline Pakistan & 0.958 & 10.481 & 0.000 \\
\hline Bangladesh & 0.981 & 8.358 & 0.000 \\
\hline Malaysia & 0.856 & 15.359 & 0.000 \\
\hline Indonesia & 0.924 & 19.544 & 0.000 \\
\hline Thailand & 0.883 & 22.894 & 0.000 \\
\hline Vietnam & 0.893 & 7.437 & 0.000 \\
\hline Korea & 0.785 & 15.464 & 0.000 \\
\hline Japan & 0.853 & 7.829 & 0.000 \\
\hline & Source: authors' estimation &
\end{tabular}

In the further stage, we used a unit root test focused on various quantiles to confirm the stationary features of T\&C manufacturing and energy intensity in all countries. The findings of the quantile unit root tests are reported in Table 3. It comprises a persistence parameter $\alpha(\tau)$ value and $t$-statistics of both variables in all nations. This table, in addition, reveals the parameter across various eleven quantiles from $\{0.05,0.10, \ldots .0 .95\}$. The discoveries of quantile unit root estimations showed that both variables are indicating non-stationary behavior at the level. This finding confirms that T\&C manufacturing and energy intensity have a unique order of integration in all countries.

The present investigation employed quantile cointegration to research the long-run non-linear relationship among T\&C and energy intensity in different countries. The findings of quantile cointegration are displayed in Table 4. This table shows the $\alpha$ and $\delta$, which are two unique estimations near to the level of significance at $1 \%, 5 \%$, and $10 \%$, respectively. The results of quantile cointegration assert an essential non-linear long-run relationship among T\&C manufacturing and energy intensity in all countries. Finally, the authors utilized QQ regression to explore the impact of energy intensity of $T \& C$ production on all top selected Asian textile and clothing producing nations.

The findings of $Q Q$ regression are pictured in Figure 1. The authors have reported the graphical portrayal for all ten selected Asian nations using the x-axis for T\&C manufacturing, y-axis for energy intensity, and the z-axis as the cross-tabulation coefficient of the T\&C producing and energy intensity for all selected Asian nations. Figure 1 clarifies the impact of energy intensity of T\&C production on all ten selected Asian economies at various quantile appropriations. 
Table 3. Quintile Unit Root Test.

\begin{tabular}{|c|c|c|c|c|c|c|c|c|}
\hline \multirow{3}{*}{ Quantile } & \multicolumn{4}{|c|}{ China } & \multicolumn{4}{|c|}{ India } \\
\hline & \multicolumn{2}{|c|}{$T \& C$} & \multicolumn{2}{|c|}{ ENI } & \multicolumn{2}{|c|}{$\mathrm{T} \& \mathrm{C}$} & \multicolumn{2}{|c|}{ ENI } \\
\hline & $\alpha(\tau)$ & t-stats & $\alpha(\tau)$ & t-stats & $\alpha(\tau)$ & t-stats & $\alpha(\tau)$ & t-stats \\
\hline 0.05 & 0.873 & 0.05 & 0.847 & -0.112 & 0.804 & -1.36 & 0.862 & -0.254 \\
\hline 0.1 & 0.873 & 0.152 & 0.854 & -0.145 & 0.881 & 0.331 & 0.863 & -0.309 \\
\hline 0.2 & 0.87 & -1.171 & 0.844 & -2.426 & 0.864 & -0.879 & 0.864 & -2.124 \\
\hline 0.3 & 0.872 & -0.39 & 0.849 & -2.346 & 0.859 & -1.671 & 0.866 & -2.252 \\
\hline 0.4 & 0.871 & -1.083 & 0.859 & -1.754 & 0.86 & -1.486 & 0.87 & -1.343 \\
\hline 0.5 & 0.871 & -2.315 & 0.86 & -2.465 & 0.859 & -1.374 & 0.87 & -0.989 \\
\hline 0.6 & 0.871 & -1.276 & 0.858 & -2.165 & 0.857 & -1.399 & 0.87 & -0.916 \\
\hline 0.7 & 0.871 & -1.918 & 0.849 & -2.087 & 0.854 & -1.67 & 0.869 & -0.932 \\
\hline 0.8 & 0.87 & -1.764 & 0.824 & -1.229 & 0.837 & -1.728 & 0.873 & 0.353 \\
\hline 0.9 & 0.871 & -0.1 & 0.806 & -0.704 & 0.854 & -0.414 & 0.876 & 0.134 \\
\hline \multirow[t]{2}{*}{0.95} & 0.864 & -0.601 & 0.753 & -0.922 & 0.856 & -0.244 & 0.872 & -0.008 \\
\hline & \multicolumn{4}{|c|}{ Pakistan } & \multicolumn{4}{|c|}{ Bangladesh } \\
\hline \multirow[t]{2}{*}{ Quantile } & \multicolumn{2}{|c|}{$\mathrm{T} \& \mathrm{C}$} & \multicolumn{2}{|c|}{ ENI } & \multicolumn{2}{|c|}{$\mathrm{T} \& \mathrm{C}$} & \multicolumn{2}{|c|}{ ENI } \\
\hline & $\alpha(\tau)$ & t-stats & $\alpha(\tau)$ & t-stats & $\alpha(\tau)$ & t-stats & $\alpha(\tau)$ & t-stats \\
\hline 0.05 & 0.847 & -0.509 & 0.866 & -0.099 & 0.855 & -0.322 & 0.853 & -0.218 \\
\hline 0.1 & 0.854 & -1.768 & 0.873 & 0.027 & 0.859 & -1.412 & 0.858 & -0.718 \\
\hline 0.2 & 0.853 & -2.236 & 0.867 & -0.632 & 0.862 & -1.796 & 0.867 & -0.439 \\
\hline 0.3 & 0.854 & -2.054 & 0.87 & -0.414 & 0.864 & -1.61 & 0.864 & -1.137 \\
\hline 0.4 & 0.855 & -1.927 & 0.87 & -1.051 & 0.867 & -1.616 & 0.863 & -1.718 \\
\hline 0.5 & 0.855 & -2.071 & 0.87 & -2.262 & 0.868 & -1.673 & 0.862 & -2.076 \\
\hline 0.6 & 0.856 & -0.99 & 0.87 & -1.114 & 0.863 & -1.745 & 0.862 & -1.722 \\
\hline 0.7 & 0.857 & -1.314 & 0.868 & -0.832 & 0.862 & -1.707 & 0.862 & -1.646 \\
\hline 0.8 & 0.857 & -1.456 & 0.867 & -0.627 & 0.863 & -1.706 & 0.862 & -1.011 \\
\hline 0.9 & 0.849 & -1.721 & 0.853 & -0.674 & 0.859 & -0.7 & 0.869 & -0.12 \\
\hline \multirow[t]{2}{*}{0.95} & 0.845 & -0.583 & 0.848 & -0.383 & 0.855 & -0.481 & 0.829 & -0.347 \\
\hline & \multicolumn{4}{|c|}{ Malaysia } & \multicolumn{4}{|c|}{ Indonesia } \\
\hline \multirow[t]{2}{*}{ Quantile } & \multicolumn{2}{|c|}{$\mathrm{T} \& \mathrm{C}$} & \multicolumn{2}{|c|}{ ENI } & \multicolumn{2}{|c|}{$\mathrm{T} \& \mathrm{C}$} & \multicolumn{2}{|c|}{ ENI } \\
\hline & $\alpha(\tau)$ & t-stats & $\alpha(\tau)$ & t-stats & $\alpha(\tau)$ & t-stats & $\alpha(\tau)$ & t-stats \\
\hline 0.05 & 0.849 & -1.524 & 0.873 & 0.588 & 0.896 & 0.052 & 0.869 & -0.115 \\
\hline 0.1 & 0.86 & -2.133 & 0.873 & 0.788 & 0.896 & 0.156 & 0.876 & -0.149 \\
\hline 0.2 & 0.857 & -1.726 & 0.872 & 1.39 & 0.893 & -1.202 & 0.866 & -2.49 \\
\hline 0.3 & 0.867 & -1.878 & 0.87 & 1.407 & 0.895 & -0.4 & 0.872 & -2.408 \\
\hline 0.4 & 0.868 & -1.544 & 0.871 & 0.737 & 0.894 & -1.111 & 0.882 & -1.801 \\
\hline 0.5 & 0.867 & -1.75 & 0.871 & -0.617 & 0.894 & -2.376 & 0.883 & -2.53 \\
\hline 0.6 & 0.868 & -1.806 & 0.869 & -1.362 & 0.894 & -1.309 & 0.881 & -2.222 \\
\hline 0.7 & 0.867 & -1.918 & 0.865 & -0.894 & 0.894 & -1.969 & 0.872 & -2.143 \\
\hline 0.8 & 0.858 & -2.035 & 0.86 & -0.4 & 0.893 & -1.811 & 0.846 & -1.261 \\
\hline 0.9 & 0.857 & -0.85 & 0.774 & -1.724 & 0.894 & -0.103 & 0.827 & -0.723 \\
\hline 0.95 & 0.858 & -0.588 & 0.662 & -1.707 & 0.887 & -0.617 & 0.773 & -0.947 \\
\hline
\end{tabular}


Table 3. Cont.

\begin{tabular}{|c|c|c|c|c|c|c|c|c|}
\hline \multirow{3}{*}{ Quantile } & \multicolumn{4}{|c|}{ Thailand } & \multicolumn{4}{|c|}{ Vietnam } \\
\hline & \multicolumn{2}{|c|}{$\mathrm{T} \& \mathrm{C}$} & \multicolumn{2}{|c|}{ ENI } & \multicolumn{2}{|c|}{$\mathrm{T} \& \mathrm{C}$} & \multicolumn{2}{|c|}{ ENI } \\
\hline & $\alpha(\tau)$ & t-stats & $\alpha(\tau)$ & t-stats & $\alpha(\tau)$ & t-stats & $\alpha(\tau)$ & t-stats \\
\hline 0.05 & 0.825 & -1.396 & 0.885 & -0.261 & 0.87 & -0.522 & 0.889 & -0.102 \\
\hline 0.1 & 0.905 & 0.34 & 0.886 & -0.317 & 0.877 & -1.814 & 0.896 & 0.027 \\
\hline 0.2 & 0.887 & -0.902 & 0.887 & -2.18 & 0.875 & -2.295 & 0.89 & -0.648 \\
\hline 0.3 & 0.882 & -1.715 & 0.889 & -2.312 & 0.876 & -2.108 & 0.893 & -0.424 \\
\hline 0.4 & 0.882 & -1.525 & 0.893 & -1.378 & 0.877 & -1.978 & 0.893 & -1.079 \\
\hline 0.5 & 0.882 & -1.41 & 0.893 & -1.016 & 0.878 & -2.126 & 0.893 & -2.321 \\
\hline 0.6 & 0.88 & -1.436 & 0.893 & -0.94 & 0.878 & -1.016 & 0.893 & -1.143 \\
\hline 0.7 & 0.876 & -1.714 & 0.892 & -0.956 & 0.879 & -1.349 & 0.891 & -0.854 \\
\hline 0.8 & 0.859 & -1.773 & 0.897 & 0.362 & 0.88 & -1.494 & 0.89 & -0.643 \\
\hline 0.9 & 0.876 & -0.425 & 0.899 & 0.138 & 0.871 & -1.767 & 0.875 & -0.692 \\
\hline \multirow[t]{2}{*}{0.95} & 0.879 & -0.251 & 0.895 & -0.009 & 0.868 & -0.598 & 0.871 & -0.393 \\
\hline & \multicolumn{4}{|c|}{ South Korea } & \multicolumn{4}{|c|}{ Japan } \\
\hline \multirow[t]{2}{*}{ Quantile } & \multicolumn{2}{|c|}{$\mathrm{T} \& \mathrm{C}$} & \multicolumn{2}{|c|}{ ENI } & \multicolumn{2}{|c|}{$T \& C$} & \multicolumn{2}{|c|}{ ENI } \\
\hline & $\alpha(\tau)$ & t-stats & $\alpha(\tau)$ & t-stats & $\alpha(\tau)$ & t-stats & $\alpha(\tau)$ & t-stats \\
\hline 0.05 & 0.877 & -0.331 & 0.876 & -0.224 & 0.871 & -1.565 & 0.896 & 0.604 \\
\hline 0.1 & 0.882 & -1.45 & 0.881 & -0.737 & 0.882 & -2.19 & 0.896 & 0.809 \\
\hline 0.2 & 0.884 & -1.844 & 0.89 & -0.451 & 0.88 & -1.772 & 0.895 & 1.427 \\
\hline 0.3 & 0.887 & -1.653 & 0.887 & -1.167 & 0.89 & -1.928 & 0.894 & 1.444 \\
\hline 0.4 & 0.89 & -1.658 & 0.886 & -1.763 & 0.89 & -1.584 & 0.894 & 0.756 \\
\hline 0.5 & 0.891 & -1.717 & 0.885 & -2.131 & 0.89 & -1.796 & 0.894 & -0.633 \\
\hline 0.6 & 0.886 & -1.791 & 0.885 & -1.768 & 0.891 & -1.854 & 0.892 & -1.398 \\
\hline 0.7 & 0.885 & -1.752 & 0.885 & -1.69 & 0.89 & -1.969 & 0.888 & -0.918 \\
\hline 0.8 & 0.886 & -1.751 & 0.885 & -1.038 & 0.881 & -2.089 & 0.883 & -0.41 \\
\hline 0.9 & 0.881 & -0.719 & 0.892 & -0.123 & 0.88 & -0.872 & 0.795 & -1.769 \\
\hline 0.95 & 0.878 & -0.494 & 0.85 & -0.356 & 0.881 & -0.603 & 0.68 & -1.752 \\
\hline & & & Sourc & uthors' $\mathrm{E}$ & ation & & & \\
\hline
\end{tabular}


Table 4. Quintile Cointegration Test.

\begin{tabular}{|c|c|c|c|c|c|c|c|c|c|c|c|}
\hline & & China & & & & & & Indonesia & & & \\
\hline Model & Coefficient & $\begin{array}{l}\text { Supremum } \\
\text { norm } \\
\text { value }\end{array}$ & $\begin{array}{c}\text { Critical } \\
\text { Value at } \\
1 \%\end{array}$ & $\begin{array}{c}\text { Critical } \\
\text { Value at } \\
5 \%\end{array}$ & $\begin{array}{c}\text { Critical } \\
\text { Value at } \\
10 \%\end{array}$ & Model & Coefficient & $\begin{array}{l}\text { Supremum } \\
\text { norm } \\
\text { value }\end{array}$ & $\begin{array}{c}\text { Critical } \\
\text { Value at } \\
1 \%\end{array}$ & $\begin{array}{c}\text { Critical } \\
\text { Value at } \\
5 \%\end{array}$ & $\begin{array}{c}\text { Critical } \\
\text { Value at } \\
10 \%\end{array}$ \\
\hline \multirow{2}{*}{ ENI $_{t}$ vs. $T \& C_{t}$} & $\alpha$ & 2321.246 & 1118.771 & 835.246 & 293.126 & \multirow{2}{*}{$\begin{array}{l}\text { ENI }_{t} \text { vs. } \\
\text { T\&C }_{t}\end{array}$} & $\mathrm{~A}$ & 1110.689 & 535.319 & 399.655 & 140.257 \\
\hline & $\delta$ & 465.286 & 244.154 & 136.81 & 119.346 & & $\Delta$ & 222.634 & 116.825 & 65.462 & 57.106 \\
\hline \multicolumn{5}{|c|}{ India } & \multicolumn{7}{|c|}{ Thailand } \\
\hline Model & Coefficient & $\begin{array}{l}\text { Supremum } \\
\text { norm } \\
\text { value }\end{array}$ & $\begin{array}{c}\text { Critical } \\
\text { Value at } \\
1 \%\end{array}$ & $\begin{array}{c}\text { Critical } \\
\text { Value at } \\
5 \%\end{array}$ & $\begin{array}{c}\text { Critical } \\
\text { Value at } \\
10 \%\end{array}$ & Model & Coefficient & $\begin{array}{l}\text { Supremum } \\
\text { norm } \\
\text { value }\end{array}$ & $\begin{array}{c}\text { Critical } \\
\text { Value at } \\
1 \%\end{array}$ & $\begin{array}{c}\text { Critical } \\
\text { Value at } \\
5 \%\end{array}$ & $\begin{array}{c}\text { Critical } \\
\text { Value at } \\
10 \%\end{array}$ \\
\hline \multirow{2}{*}{ ENI $_{t}$ vs. $T \& C_{t}$} & $\alpha$ & 3137.966 & 959.516 & 524.846 & 257.649 & \multirow{2}{*}{$\begin{array}{c}\mathrm{ENI}_{\mathrm{t}} \text { vs. } \\
{\mathrm{T} \& \mathrm{C}_{\mathrm{t}}}\end{array}$} & A & 1501.48 & 459.117 & 251.132 & 123.282 \\
\hline & $\delta$ & 854.036 & 319.921 & 190.71 & 137.41 & & $\Delta$ & 408.646 & 153.078 & 91.252 & 65.749 \\
\hline \multicolumn{5}{|c|}{ Pakistan } & \multicolumn{7}{|c|}{ Vietnam } \\
\hline Model & Coefficient & $\begin{array}{l}\text { Supremum } \\
\text { norm } \\
\text { value }\end{array}$ & $\begin{array}{c}\text { Critical } \\
\text { Value at } \\
1 \%\end{array}$ & $\begin{array}{c}\text { Critical } \\
\text { Value at } \\
5 \%\end{array}$ & $\begin{array}{c}\text { Critical } \\
\text { Value at } \\
10 \%\end{array}$ & Model & Coefficient & $\begin{array}{l}\text { Supremum } \\
\text { norm } \\
\text { value }\end{array}$ & $\begin{array}{c}\text { Critical } \\
\text { Value at } \\
1 \%\end{array}$ & $\begin{array}{c}\text { Critical } \\
\text { Value at } \\
5 \%\end{array}$ & $\begin{array}{c}\text { Critical } \\
\text { Value at } \\
10 \%\end{array}$ \\
\hline \multirow{2}{*}{ ENI $_{t}$ vs. $T \& C_{t}$} & $\alpha$ & 1907.117 & 1253.856 & 765.913 & 514.174 & \multirow{2}{*}{$\begin{array}{c}\mathrm{ENI}_{\mathrm{t}} \text { vs. } \\
\mathrm{T}_{\mathrm{C}} \mathrm{C}_{\mathrm{t}}\end{array}$} & $\mathrm{A}$ & 912.533 & 599.955 & 366.48 & 246.026 \\
\hline & $\delta$ & 1118.8 & 646.329 & 379.385 & 165.604 & & $\Delta$ & 535.333 & 309.261 & 181.531 & 79.24 \\
\hline \multicolumn{6}{|c|}{ Bangladesh } & \multicolumn{6}{|c|}{ South Korea } \\
\hline Model & Coefficient & $\begin{array}{l}\text { Supremum } \\
\text { norm } \\
\text { value }\end{array}$ & $\begin{array}{c}\text { Critical } \\
\text { Value at } \\
1 \%\end{array}$ & $\begin{array}{c}\text { Critical } \\
\text { Value at } \\
5 \%\end{array}$ & $\begin{array}{c}\text { Critical } \\
\text { Value at } \\
10 \%\end{array}$ & Model & Coefficient & $\begin{array}{l}\text { Supremum } \\
\text { norm } \\
\text { value }\end{array}$ & $\begin{array}{c}\text { Critical } \\
\text { Value at } \\
1 \%\end{array}$ & $\begin{array}{c}\text { Critical } \\
\text { Value at } \\
5 \%\end{array}$ & $\begin{array}{c}\text { Critical } \\
\text { Value at } \\
10 \%\end{array}$ \\
\hline \multirow{2}{*}{ ENI $_{t}$ vs. $T \& C_{t}$} & $\alpha$ & 4304.168 & 1254.004 & 844.698 & 466.681 & \multirow{2}{*}{$\begin{array}{c}\text { ENI }_{t} \text { vs. } \\
\text { T\&C }_{t}\end{array}$} & $\alpha$ & 2059.494 & 600.026 & 404.178 & 223.301 \\
\hline & $\delta$ & 2436.524 & 970.314 & 563.462 & 293.199 & & $\delta$ & 1165.848 & 464.284 & 269.61 & 140.292 \\
\hline \multicolumn{6}{|c|}{ Malaysia } & \multicolumn{6}{|c|}{ Japan } \\
\hline Model & Coefficient & $\begin{array}{l}\text { Supremum } \\
\text { norm } \\
\text { value }\end{array}$ & $\begin{array}{c}\text { Critical } \\
\text { Value at } \\
1 \%\end{array}$ & $\begin{array}{c}\text { Critical } \\
\text { Value at } \\
5 \%\end{array}$ & $\begin{array}{c}\text { Critical } \\
\text { Value at } \\
10 \%\end{array}$ & Model & Coefficient & $\begin{array}{l}\text { Supremum } \\
\text { norm } \\
\text { value }\end{array}$ & $\begin{array}{c}\text { Critical } \\
\text { Value at } \\
1 \%\end{array}$ & $\begin{array}{c}\text { Critical } \\
\text { Value at } \\
5 \%\end{array}$ & $\begin{array}{c}\text { Critical } \\
\text { Value at } \\
10 \%\end{array}$ \\
\hline \multirow{2}{*}{ ENI $_{t}$ vs. $T \& C_{t}$} & $\alpha$ & 2937.394 & 1501.96 & 1071.565 & 822.234 & \multirow{2}{*}{$\begin{array}{l}\text { ENI }_{t} \text { vs. } \\
\text { T\&C }_{t}\end{array}$} & $\alpha$ & 1405.509 & 718.67 & 512.731 & 393.429 \\
\hline & $\delta$ & 1240.125 & 862.113 & 421.565 & 257.702 & & $\delta$ & 593.385 & 412.511 & 201.714 & 123.307 \\
\hline
\end{tabular}

Note: This table presents the results of the quantile cointegration test of Xiao (2009) for the logarithm of the Textile \& Clothing (T\&C) and per capita of carbon dioxide emission $\left(\mathrm{CO}_{2}\right)$.

Abbreviations ENI, energy intensity; T\&C, textiles and clothing sector. 


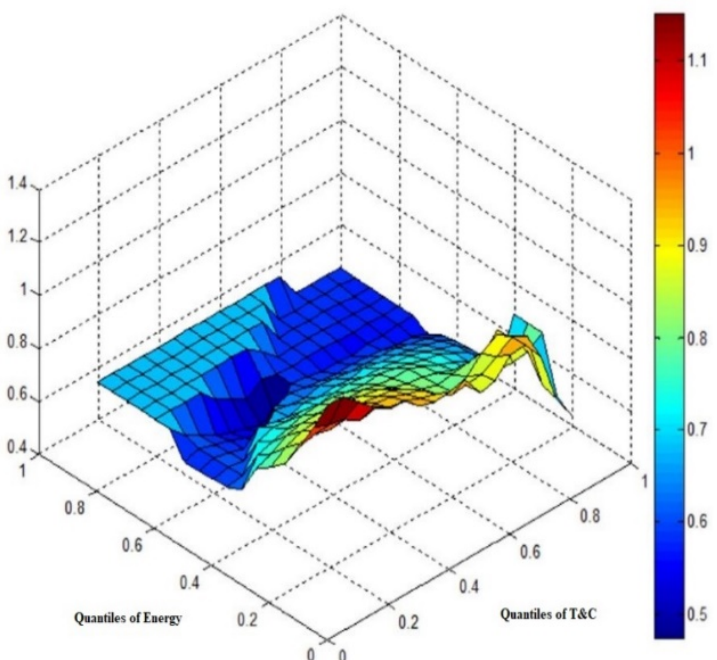

(i) China

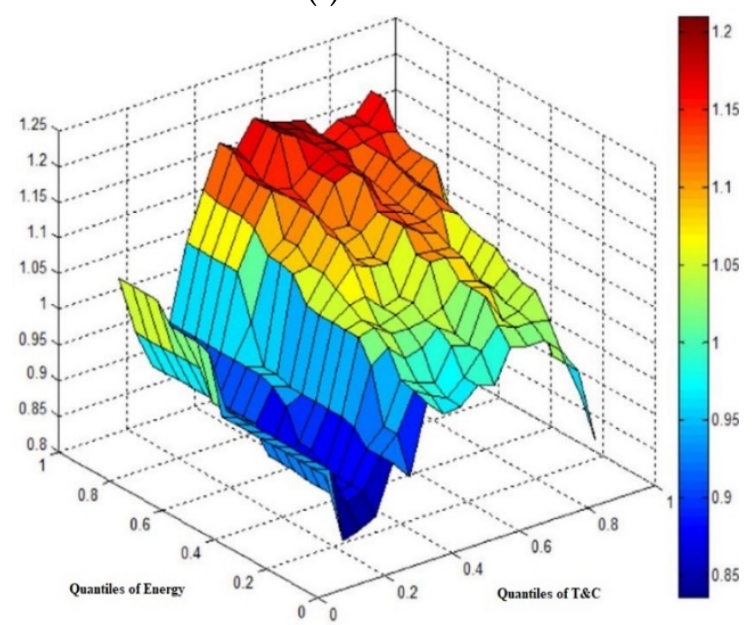

(iii) Pakistan

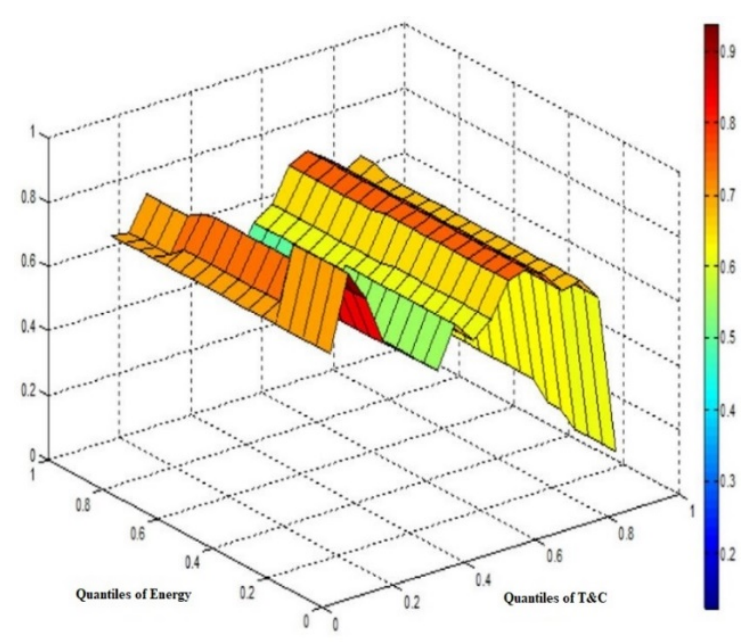

(v) Malaysia

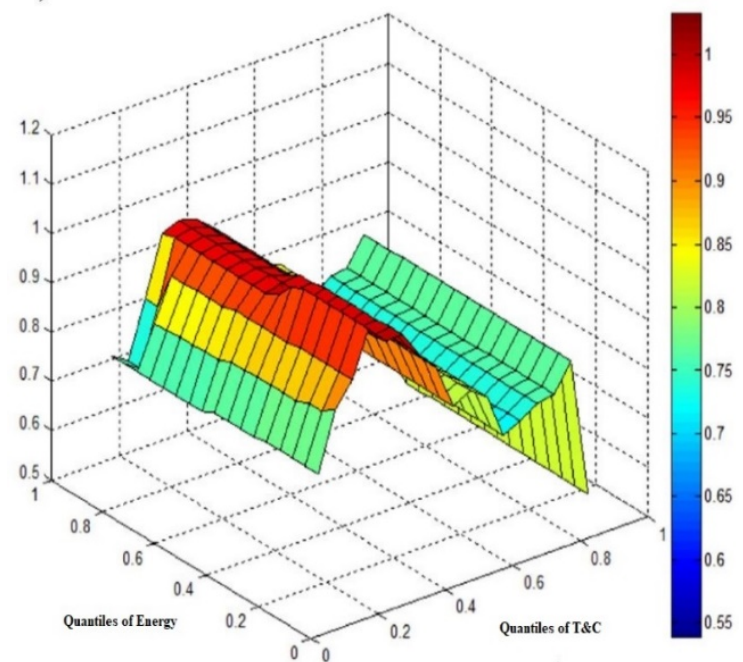

(ii) India

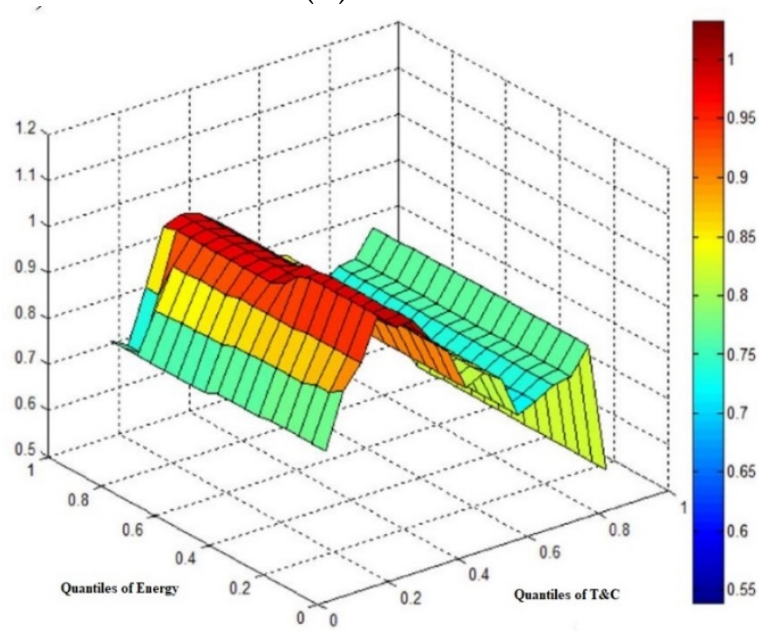

(iv) Bangladesh

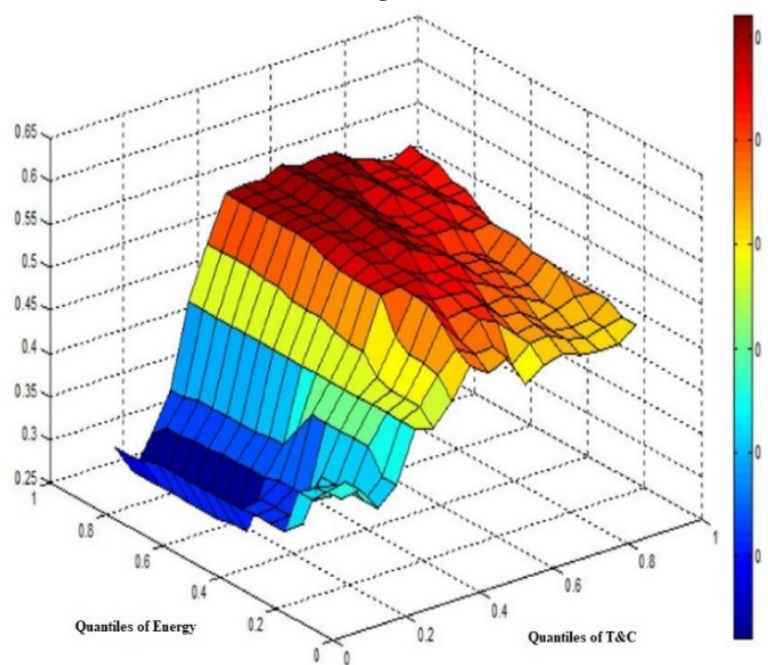

(vi) Indonesia

Figure 1. Cont. 


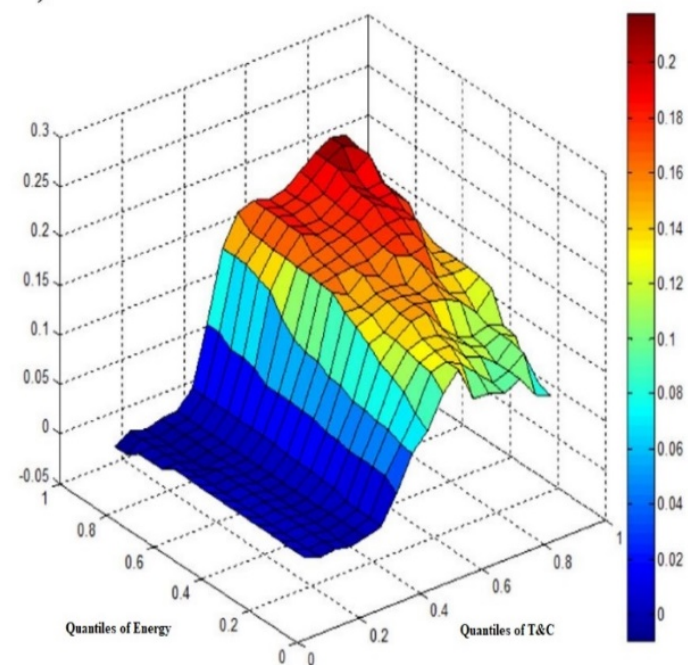

(vii) Thailand

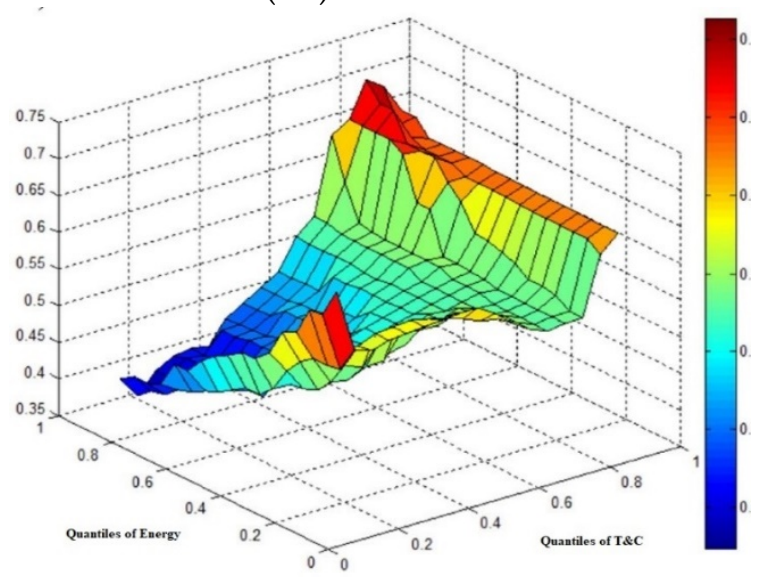

(ix) South Korea

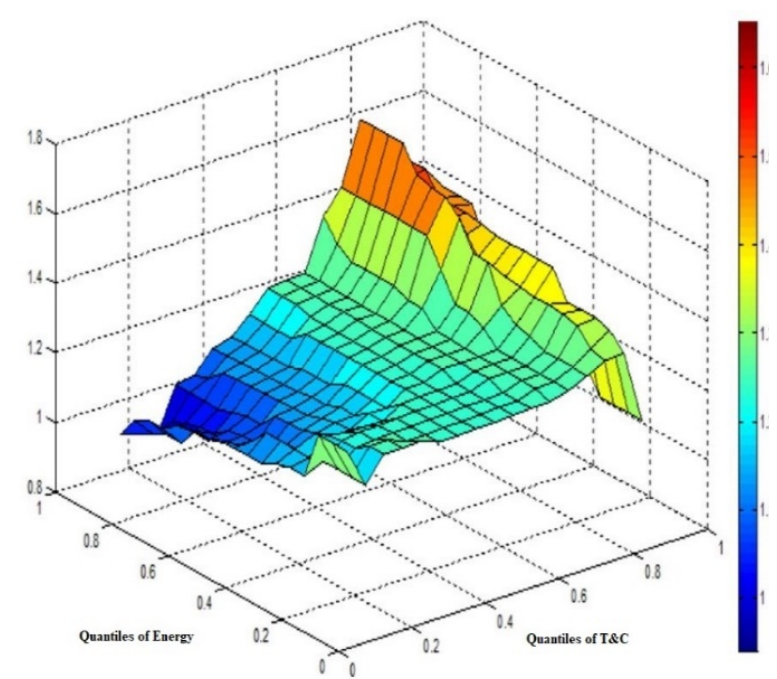

(viii) Vietnam

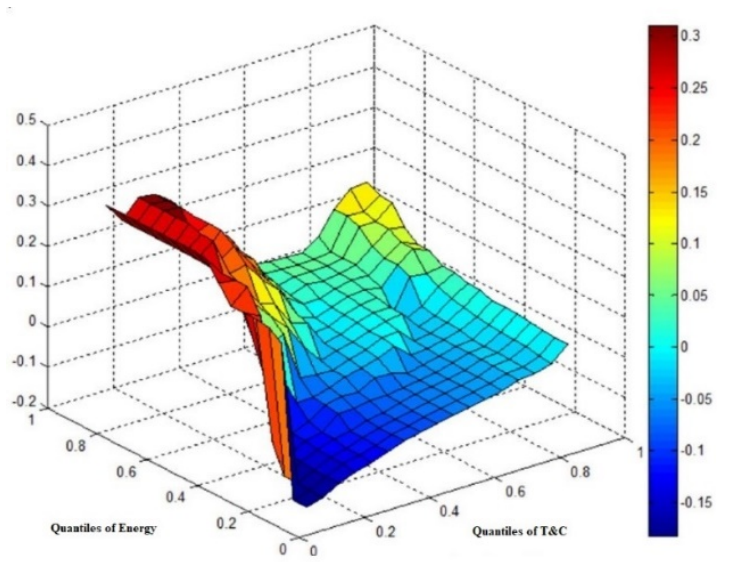

(x) Japan

Figure 1. Results of quantile-on-quantile regression.

In China, the results confirm that the effect of $T \& C$ production on energy intensity is significant and substantial to the overall grouping of quantiles. Furthermore, the impact of $\mathrm{T} \& \mathrm{C}$ production on energy intensity is perceptible in the low quantiles of both variables (i.e., $0.05-0.40$ ), suggesting that $T \& C$ manufacturing actually has a positive effect on energy intensity at all quantile distributions; however, the effect is stronger in the low tails of both variables. Overall, the results of QQ suggest that the effect of energy intensity on $T \& C$ manufacturing is positive and significant. However, as the manufacturing of T\&C increases, the level of energy intensity decreases and becomes weaker. In this situation, the Chinese government and local investors needs to implement some green technology to reduce the energy consumption, which ultimately decreases energy inefficiency in the Chinese economy.

The effect of T\&C production on energy intensity is very similar in the cases of Malaysia and India. The results suggested that the impact of $T \& C$ production on energy intensity is significant as the maximum number of various quantiles. The highest effect of $T \& C$ manufacturing on energy intensity is reported at lower-middle quantiles of $\mathrm{T} \& \mathrm{C}(0.25-0.50)$ and also across all quantiles of energy intensity $(0.05-0.95)$. Technically speaking, the results of QQ regression suggest that the effect of $T \& C$ production on energy intensity is significant and positive at lower-middle quantiles of T\&C production; however, the effect becomes weaker at a high level of T\&C production. In the case of South Korea, Vietnam and Bangladesh, the results confirm that the effect of T\&C production on energy intensity is significant and noteworthy across all combination of quantiles. Furthermore, the impact of $\mathrm{T} \& \mathrm{C}$ production on energy intensity is noticeable in the high quantiles of $T \& C$ production (i.e., $0.85-0.95$ ) and all quantiles 
of energy intensity (i.e., 0.05-0.95), suggesting that T\&C manufacturing has a positive effect on energy intensity at all quantile distributions. However, the effect is stronger in the high tails (maximum) of $T \& C$ production. In general, the results of $Q Q$ confirm that the effect of $T \& C$ manufacturing on energy intensity is positive and significant. However, as the manufacturing of $\mathrm{T} \& \mathrm{C}$ decreases, the level of energy intensity decreases too. This finding suggested that these Asian countries' energy levels are very much dependent on textile and clothing manufacturing. Therefore, the governments of these countries need to shift the textile industry towards renewable energy consumption to reduce energy inefficiency. Interestingly in the case of Pakistan, Indonesia and Thailand, the graphs of QQ confirm that the influence of $T \& C$ production on energy intensity is important and remarkable in all mixtures of quantiles. Additionally, the influence of T\&C production on energy intensity is visible in the high quantiles of T\&C production (i.e., 0.80-0.95) and high quantiles of energy intensity (i.e., 0.75-0.95), implying that $\mathrm{T} \& \mathrm{C}$ manufacturing essentially has a positive effect on energy intensity at all quantile distributions. However, the effect is more robust in the high tails (maximum) of T\&C production and energy intensity. In summary, the results of $Q Q$ confirm that the effect of $T \& C$ manufacturing on energy intensity is positive and significant. However, as the manufacturing of T\&C increases, the level of energy intensity increases too. In the case of Japan, the outcomes confirm that the impact of T\&C production on energy intensity is significant and considerable across entire sets of quantiles.

Furthermore, the effect of $T \& C$ production on energy intensity is observable in the low quantiles of T\&C production (i.e., 0.05-0.10) and all quantiles of energy intensity (0.05-0.95), suggesting that $T \& C$ manufacturing actually have a positive effect on energy intensity at low quantiles. However, the effect is stronger in the low tails of T\&C production. On the other hand, while seeing the effect of T\&C production at high quantiles $(0.50-0.95)$, it can be found that it gives a negative impact on energy intensity. We suggest that the increase in T\&C production helps to reduce the energy intensity in the Japanese economy. This finding suggests that the direction of the government and policymakers is in the right path, and it reduces the level of energy inefficiency with the help of textile and clothing production.

In the final step, the present study aims to investigate the causal relationship between T\&C production and energy intensity. In doing so, the authors applied Granger causality in quantiles to examine the cause-and-effect connection between both variables. The results of Granger causality in quantiles are reported in Table 5 that shows the p-values of both directional causal relationships. The results confirm bi-directional causal connection between textile and clothing manufacturing and energy intensity in all selected countries, except Thailand and Japan. The results show a uni-directional causal connection between textile and clothing production and energy intensity in the cases of Japan and Thailand, where causality is running from textile and clothing production to energy intensity and does not reverse. 
Table 5. Granger Causality in Quintile Test Results.

\begin{tabular}{|c|c|c|c|c|c|c|c|c|c|c|c|c|}
\hline \multicolumn{13}{|c|}{ China } \\
\hline Causality & {$[0.05-0.95]$} & 0.05 & 0.1 & 0.2 & 0.3 & 0.4 & 0.5 & 0.6 & 0.7 & 0.8 & 0.9 & 0.95 \\
\hline$\Delta \mathrm{T} \& \mathrm{C}_{\mathrm{t}}$ to $\Delta \mathrm{ENI}_{\mathrm{t}}$ & 0.000 & 0.000 & 0.000 & 0.000 & 0.000 & 0.000 & 0.000 & 0.000 & 0.000 & 0.000 & 0.000 & 0.000 \\
\hline$\Delta \mathrm{ENI}_{\mathrm{t}}$ to $\Delta \mathrm{T} \& \mathrm{C}_{\mathrm{t}}$ & 0.000 & 0.000 & 0.000 & 0.000 & 0.000 & 0.000 & 0.000 & 0.000 & 0.000 & 0.000 & 0.000 & 0.000 \\
\hline \multicolumn{13}{|c|}{ India } \\
\hline$\Delta \mathrm{T} \& \mathrm{C}_{\mathrm{t}}$ to $\Delta \mathrm{ENI}_{\mathrm{t}}$ & 0.000 & 0.000 & 0.000 & 0.000 & 0.000 & 0.000 & 0.000 & 0.000 & 0.000 & 0.000 & 0.000 & 0.000 \\
\hline$\Delta \mathrm{ENI}_{\mathrm{t}}$ to $\Delta \mathrm{T} \& \mathrm{C}_{\mathrm{t}}$ & 0.000 & 0.000 & 0.000 & 0.000 & 0.000 & 0.000 & 0.000 & 0.000 & 0.000 & 0.000 & 0.000 & 0.000 \\
\hline \multicolumn{13}{|c|}{ Pakistan } \\
\hline$\Delta \mathrm{T} \& \mathrm{C}_{\mathrm{t}}$ to $\Delta \mathrm{ENI}_{\mathrm{t}}$ & 0.000 & 0.000 & 0.000 & 0.000 & 0.000 & 0.000 & 0.000 & 0.000 & 0.000 & 0.000 & 0.000 & 0.000 \\
\hline$\Delta \mathrm{ENI}_{\mathrm{t}}$ to $\Delta \mathrm{T} \& \mathrm{C}_{\mathrm{t}}$ & 0.000 & 0.000 & 0.000 & 0.000 & 0.000 & 0.000 & 0.000 & 0.000 & 0.000 & 0.000 & 0.000 & 0.000 \\
\hline \multicolumn{13}{|c|}{ Bangladesh } \\
\hline$\Delta \mathrm{T}^{2} \mathrm{C}_{\mathrm{t}}$ to $\Delta \mathrm{ENI}_{\mathrm{t}}$ & 0.000 & 0.000 & 0.000 & 0.000 & 0.000 & 0.000 & 0.000 & 0.000 & 0.000 & 0.000 & 0.000 & 0.000 \\
\hline$\Delta \mathrm{ENI}_{\mathrm{t}}$ to $\Delta \mathrm{T} \& \mathrm{C}_{\mathrm{t}}$ & 0.000 & 0.000 & 0.000 & 0.000 & 0.000 & 0.000 & 0.000 & 0.000 & 0.000 & 0.000 & 0.000 & 0.000 \\
\hline \multicolumn{13}{|c|}{ Malaysia } \\
\hline$\Delta \mathrm{T} \& \mathrm{C}_{\mathrm{t}}$ to $\Delta \mathrm{ENI}_{\mathrm{t}}$ & 0.000 & 0.000 & 0.000 & 0.000 & 0.000 & 0.000 & 0.000 & 0.000 & 0.000 & 0.000 & 0.000 & 0.000 \\
\hline$\Delta \mathrm{ENI}_{\mathrm{t}}$ to $\Delta \mathrm{T} \& \mathrm{C}_{\mathrm{t}}$ & 0.000 & 0.000 & 0.000 & 0.000 & 0.000 & 0.000 & 0.000 & 0.000 & 0.000 & 0.000 & 0.000 & 0.000 \\
\hline \multicolumn{13}{|c|}{ Indonesia } \\
\hline$\Delta \mathrm{T}_{2} \mathrm{C}_{\mathrm{t}}$ to $\Delta \mathrm{ENI}_{\mathrm{t}}$ & 0.000 & 0.000 & 0.000 & 0.000 & 0.000 & 0.000 & 0.000 & 0.000 & 0.000 & 0.000 & 0.000 & 0.000 \\
\hline$\Delta \mathrm{ENI}_{\mathrm{t}}$ to $\Delta \mathrm{T} \& \mathrm{C}_{\mathrm{t}}$ & 0.000 & 0.000 & 0.000 & 0.000 & 0.000 & 0.000 & 0.000 & 0.000 & 0.000 & 0.000 & 0.000 & 0.000 \\
\hline \multicolumn{13}{|c|}{ Thailand } \\
\hline$\Delta \mathrm{T} \& \mathrm{C}_{\mathrm{t}}$ to $\Delta \mathrm{ENI}_{\mathrm{t}}$ & 0.000 & 0.000 & 0.000 & 0.000 & 0.000 & 0.000 & 0.000 & 0.000 & 0.000 & 0.000 & 0.000 & 0.000 \\
\hline$\Delta \mathrm{ENI}_{\mathrm{t}}$ to $\Delta \mathrm{T} \& \mathrm{C}_{\mathrm{t}}$ & 0.195 & 0.493 & 0.543 & 0.584 & 0.603 & 0.689 & 0.712 & 0.642 & 0.543 & 0.49 & 0.327 & 0.215 \\
\hline
\end{tabular}


Table 5. Cont

\begin{tabular}{|c|c|c|c|c|c|c|c|c|c|c|c|c|}
\hline \multicolumn{13}{|c|}{ Vietnam } \\
\hline$\Delta \mathrm{T} \& \mathrm{C}_{\mathrm{t}}$ to $\Delta \mathrm{ENI}_{\mathrm{t}}$ & 0.000 & 0.000 & 0.000 & 0.000 & 0.000 & 0.000 & 0.000 & 0.000 & 0.000 & 0.000 & 0.000 & 0.000 \\
\hline$\Delta \mathrm{ENI}_{\mathrm{t}}$ to $\Delta \mathrm{T} \& \mathrm{C}_{\mathrm{t}}$ & 0.000 & 0.000 & 0.000 & 0.000 & 0.000 & 0.000 & 0.000 & 0.000 & 0.000 & 0.000 & 0.000 & 0.000 \\
\hline$\Delta \mathrm{T} \& \mathrm{C}_{\mathrm{t}}$ to $\Delta \mathrm{ENI}_{\mathrm{t}}$ & 0.000 & 0.000 & 0.000 & 0.000 & 0.000 & 0.000 & 0.000 & 0.000 & 0.000 & 0.000 & 0.000 & 0.000 \\
\hline$\Delta \mathrm{ENI}_{\mathrm{t}}$ to $\Delta \mathrm{T} \& \mathrm{C}_{\mathrm{t}}$ & 0.000 & 0.000 & 0.000 & 0.000 & 0.000 & 0.000 & 0.000 & 0.000 & 0.000 & 0.000 & 0.000 & 0.000 \\
\hline \multicolumn{13}{|c|}{ Japan } \\
\hline$\Delta \mathrm{T} \& \mathrm{C}_{\mathrm{t}}$ to $\Delta \mathrm{ENI}_{\mathrm{t}}$ & 0.000 & 0.000 & 0.000 & 0.000 & 0.000 & 0.000 & 0.000 & 0.000 & 0.000 & 0.000 & 0.000 & 0.000 \\
\hline$\Delta \mathrm{ENI}_{\mathrm{t}}$ to $\Delta \mathrm{T} \& \mathrm{C}_{\mathrm{t}}$ & 0.482 & 0.148 & 0.264 & 0.331 & 0.548 & 0.427 & 0.368 & 0.301 & 0.287 & 0.216 & 0.189 & 0.167 \\
\hline \multicolumn{13}{|c|}{ Source: Authors' Estimation } \\
\hline
\end{tabular}




\section{Conclusions}

The current study has evaluated the asymmetric impact of textile manufacturing on energy intensity of ten leading Asian economies based on textile dominance. The selected countries are China, Indonesia, India, Pakistan, Bangladesh, Malaysia, South Korea, Thailand, Japan and Vietnam. The results of quantile-on-quantile analysis confirms that $T \& C$ production has a positive and significant impact on energy intensity in all selected countries. The results further suggest that a low level of $\mathrm{T} \& \mathrm{C}$ production increases the level of energy intensity in all selected countries. Conversely, at high quantiles (high level of T\&C production), the effect is also positive in all countries except Japan. On the other hand, the results of Granger causality in quantiles confirm a bidirectional causal relationship between T\&C production and energy intensity in all selected countries except Thailand and Japan, where a uni-directional causal connection between textile and clothing manufacturing and energy intensity can be found. This study recommends that governments and investors invest more in green and advanced technologies to reduce the energy intensity in Asian economies.

\section{Discussion and Future Recommendation}

The prominence of the textile industry is notable for generating foreign exchange through trade expansion, particularly in emerging economies. In many Asian countries, the textile sector is considered to be the backbone of the economy, creating employment opportunities for both men and women. However, from a environmental perspective, industrial growth is notable for carrying adverse influence, especially in regard to climate change. In recent years, climate vulnerability has been recognized as an international issue, since it is responsible for carrying numerous harmful effects on many countries' growth and sustainability. The rapid degradation of climate conditions has been found to link with increased industrialization, increased energy intensity and burning of fossil fuels [70-72]. In line with this statement, our objective was to identify the dynamic relationship between the textile industry and energy utilization across several levels of growth. In doing so, the utilized methodology has been selected to recognize the link between T\&C and ENI in numerous quantiles representing the low, medium and high levels of the studied variables. The outcomes reveal that the effect of T\&C manufacturing on energy intensity is positive and significant in all selected Asian countries. Moreover, the effect is high and is the same in India, Bangladesh and Malaysia (low T\&C production positively affects energy intensity). On the other hand, the effect of high T\&C production is significant and positive on energy intensity in the case of Indonesia, Thailand, Vietnam and Pakistan and South Korea. Finally, the present research can be extended in the future by adding multivariate modelling such as non-linearAuto-Regressive Distributed Lag (ARDL) or quantile-ARDL. Future research could also introduce other essential factors, such as $\mathrm{CO}_{2}$ emissions, economic growth and renewable energy consumption.

Author Contributions: The following was the contribution of each author of this study. M.H. has worked on the original idea. M.H. has performed the detailed conceptualization and investigation of this research. H.I.H. has finalized the methodology. H.I.H. has conducted data analysis of this research. S.K. has performed the write up of this project including the writing of original draft. S.K. has performed the data collection and data analysis. L.W.M. has written the final draft and done the review, proof reading and editing for final submission. P.S. has coordinated the methodology and data analysis stage of this research project. All authors have read and agreed to the published version of the manuscript.

Funding: This research received no external funding.

Conflicts of Interest: The authors declare no conflict of interest.

\section{References}

1. Jomo, K.S. Industrializing Malaysia: Policy, Performance, Prospects; Routledge: Abingdon, UK, 2013.

2. Huang, B.; Zhao, J.; Geng, Y.; Tian, Y.; Jiang, P. Energy-related ghg emissions of the textile industry in china. Resour. Conserv. Recycl. 2017, 119, 69-77. [CrossRef]

3. Raichurkar, P.; Ramachandran, M. Recent trends and developments in textile industry in india. Int. J. Text. Eng. Process. 2015, 1, 47-50. 
4. Chang, J.-H.; Rynhart, G.; Huynh, P. Asean in Transformation: Textiles, Clothing and Footwear: Refashioning the Future; ILO: Geneva, Switzerland, 2016.

5. Iqbal, M.S.; Shaikh, F.M.; Mahmood, B.; Shafiq, K. Development of textile industrial clusters in pakistan. Asian Soc. Sci. 2010, 6, 123. [CrossRef]

6. Ahmed, F.E. The rise of the bangladesh garment industry: Globalization, women workers, and voice. NWSA J. 2004, 34-45. [CrossRef]

7. Talukdar, D.; Meisner, C.M. Does the private sector help or hurt the environment? Evidence from carbon dioxide pollution in developing countries. World Dev. 2001, 29, 827-840. [CrossRef]

8. Safeer, A.A.; He, Y.; Abrar, M.; Ullah, A. Diagnostics of the challenges and potential solutions to improve export competitiveness in international markets: The case of pakistani readymade garments industry. J. Compet. 2019, 11, 128. [CrossRef]

9. Akhtar, P. Drivers of green supply chain initiatives and their impact on economic performance of firms: Evidence from pakistan's manufacturing sector. J. Compet. 2019, 11, 5. [CrossRef]

10. Tamazian, A.; Chousa, J.P.; Vadlamannati, K.C. Does higher economic and financial development lead to environmental degradation: Evidence from bric countries. Energy Policy 2009, 37, 246-253. [CrossRef]

11. Nowak, S.; Ulfik, A. An evaluation of regional development in the context of economic and environmental benefits. Pol. J. Manag. Stud. 2014, 10, 74-83.

12. Asumadu-Sarkodie, S.; Owusu, P.A. Carbon dioxide emission, electricity consumption, industrialization, and economic growth nexus: The beninese case. Energy Sources Part B Econ. Plan. Policy 2016, 11, 1089-1096. [CrossRef]

13. Sandin, G.; Peters, G.M. Environmental impact of textile reuse and recycling-a review. J. Clean. Prod. 2018, 184, 353-365. [CrossRef]

14. Li, Y.; Lu, L.; Tan, Y.; Wang, L.; Shen, M. Decoupling water consumption and environmental impact on textile industry by using water footprint method: A case study in china. Water 2017, 9, 124. [CrossRef]

15. Ganesan, P.; Thirugnanasambandam, M.; Rajakarunakaran, S.; Devaraj, D. Specific energy consumption and $\mathrm{CO}_{2}$ emission reduction analysis in a textile industry. Int. J. Green Energy 2015, 12, 685-693. [CrossRef]

16. Ma, Y.; Lu, A. Estimation and factors analysis of carbon emission of textile and apparel industry. Wool Text. J. 2015, 43, 62-65.

17. Yan, Y.; Wang, C.; Ding, D.; Zhang, Y.; Wu, G.; Wang, L.; Liu, X.; Du, C.; Zhang, Y.; Zhao, C. Industrial carbon footprint of several typical chinese textile fabrics. Acta Ecol. Sin. 2016, 36, 119-125. [CrossRef]

18. Nimkar, U. Sustainable chemistry: A solution to the textile industry in a developing world. Curr. Opin. Green Sustain. Chem. 2018, 9, 13-17. [CrossRef]

19. Rahman, M.M.; Kashem, M.A. Carbon emissions, energy consumption and industrial growth in bangladesh: Empirical evidence from ardl cointegration and granger causality analysis. Energy Policy 2017, 110, 600-608. [CrossRef]

20. Attari, M.I.J.; Hussain, M.; Javid, A.Y. Carbon emissions and industrial growth: An ardl analysis for pakistan. Int. J. Energy Sect. Manag. 2016, 10, 642-658. [CrossRef]

21. Odhiambo, N.M. Energy consumption and economic growth nexus in tanzania: An ardl bounds testing approach. Energy Policy 2009, 37, 617-622. [CrossRef]

22. Safa, M.S. Socio-economic factors affecting the income of small-scale agroforestry farms in hill country areas in yemen: A comparison of ols and wls determinants. Small-Scale For. Econ. Manag. Policy 2005, 4, 117-134. [CrossRef]

23. Sharif, A.; Afshan, S.; Qureshi, M.A. Idolization and ramification between globalization and ecological footprints: Evidence from quantile-on-quantile approach. Environ. Sci. Pollut. Res. 2019, 26, 11191-11211. [CrossRef]

24. Sim, N.; Zhou, H. Oil prices, us stock return, and the dependence between their quantiles. J. Bank. Financ. 2015, 55, 1-8. [CrossRef]

25. Ramanathan, R.; He, Q.; Black, A.; Ghobadian, A.; Gallear, D. Environmental regulations, innovation and firm performance: A revisit of the porter hypothesis. J. Clean. Prod. 2017, 155, 79-92. [CrossRef]

26. Fercoq, A.; Lamouri, S.; Carbone, V. Lean/green integration focused on waste reduction techniques. J. Clean. Prod. 2016, 137, 567-578. [CrossRef] 
27. Dahlbo, H.; Bachér, J.; Lähtinen, K.; Jouttijärvi, T.; Suoheimo, P.; Mattila, T.; Sironen, S.; Myllymaa, T.; Saramäki, K. Construction and demolition waste management-a holistic evaluation of environmental performance. J. Clean. Prod. 2015, 107, 333-341. [CrossRef]

28. Molina-Azorín, J.F.; Claver-Cortés, E.; Pereira-Moliner, J.; Tarí, J.J. Environmental practices and firm performance: An empirical analysis in the spanish hotel industry. J. Clean. Prod. 2009, 17, 516-524. [CrossRef]

29. Fernando, Y.; Hor, W.L. Impacts of energy management practices on energy efficiency and carbon emissions reduction: A survey of malaysian manufacturing firms. Resour. Conserv. Recycl. 2017, 126, 62-73. [CrossRef]

30. Noailly, J. Improving the energy efficiency of buildings: The impact of environmental policy on technological innovation. Energy Econ. 2012, 34, 795-806. [CrossRef]

31. Howarth, R.B.; Haddad, B.M.; Paton, B. The economics of energy efficiency: Insights from voluntary participation programs. Energy Policy 2000, 28, 477-486. [CrossRef]

32. Yeh, S.; Mishra, G.S.; Fulton, L.; Kyle, P.; McCollum, D.L.; Miller, J.; Cazzola, P.; Teter, J. Detailed assessment of global transport-energy models' structures and projections. Transp. Res. Part. D Transp. Environ. 2017, 55, 294-309. [CrossRef]

33. Achour, H.; Belloumi, M. Decomposing the influencing factors of energy consumption in tunisian transportation sector using the lmdi method. Transp. Policy 2016, 52, 64-71. [CrossRef]

34. Andrés, L.; Padilla, E. Energy intensity in road freight transport of heavy goods vehicles in spain. Energy Policy 2015, 85, 309-321. [CrossRef]

35. Dasgupta, S.; Roy, J. Analysing energy intensity trends and decoupling of growth from energy use in indian manufacturing industries during 1973-1974 to 2011-2012. Energy Effic. 2017, 10, 925-943. [CrossRef]

36. Chontanawat, J.; Wiboonchutikula, P.; Buddhivanich, A. Decomposition analysis of the change of energy intensity of manufacturing industries in thailand. Energy 2014, 77, 171-182. [CrossRef]

37. Bernard, J.-T.; Côté, B. The measurement of the energy intensity of manufacturing industries: A principal components analysis. Energy Policy 2005, 33, 221-233. [CrossRef]

38. Lin, B.; Chen, Y. Will economic infrastructure development affect the energy intensity of china's manufacturing industry? Energy Policy 2019, 132, 122-131. [CrossRef]

39. Elliott, R.J.; Sun, P.; Zhu, T. The direct and indirect effect of urbanization on energy intensity: A province-level study for china. Energy 2017, 123, 677-692. [CrossRef]

40. Zhou, X.; Zhou, D.; Wang, Q. How does information and communication technology affect china's energy intensity? A three-tier structural decomposition analysis. Energy 2018, 151, 748-759. [CrossRef]

41. Wang, D.; Han, B. The impact of ict investment on energy intensity across different regions of china. J. Renew. Sustain. Energy 2016, 8, 055901. [CrossRef]

42. Pelletier, N.; Audsley, E.; Brodt, S.; Garnett, T.; Henriksson, P.; Kendall, A.; Kramer, K.J.; Murphy, D.; Nemecek, T.; Troell, M. Energy intensity of agriculture and food systems. Annu. Rev. Environ. Resour. 2011, 36, 223-246. [CrossRef]

43. Schneider, U.A.; Smith, P. Energy intensities and greenhouse gas emission mitigation in global agriculture. Energy Effic. 2009, 2, 195-206. [CrossRef]

44. Saran, R.K.; Kumar, R.; Yadav, S. Environmental issues in textiles. Adv. Funct. Text. Polym. Fabr. Process. Appl. 2019, 129-151.

45. Naqvi, S.A.; Arshad, M.; Nadeem, F. Water footprint of cotton textile processing industries; a case study of punjab, pakistan. Am. Sci. Res. J. Eng. Technol. Sci. (Asrjets) 2018, 46, 17-24.

46. Lucato, W.C.; Costa, E.M.; de Oliveira Neto, G.C. The environmental performance of smes in the brazilian textile industry and the relationship with their financial performance. J. Environ. Manag. 2017, 203, 550-556. [CrossRef]

47. DiebaÈcker, M. Environmental and social benchmarking for industrial processes in developing countries: A pilot project for the textile industry in india, indonesia and zimbabwe. Integr. Manuf. Syst. 2000, 11, 491-500. [CrossRef]

48. You, S.; Cheng, S.; Yan, H. The impact of textile industry on china's environment. Int. J. Fash. Des. Technol. Educ. 2009, 2, 33-43. [CrossRef]

49. Chavan, R. Indian textile industry-environmental issues. Indian J. Fibre Text. Res. 2001, 26, 11-21.

50. Martínez, C.I.P. Energy use and energy efficiency development in the german and colombian textile industries. Energy Sustain. Dev. 2010, 14, 94-103. [CrossRef] 
51. Li, R.; Wu, D.D.; Jiang, H. Carbon footprint and its measurement in dyeing and finishing. Dyeing 2011, 37, 40-43.

52. Wang, H.; Xu, M.-J. Review on theoretical model of carbon emissions in textile industry chain. Shanghai Text. Sci. Technol. 2011, 7, 1-4.

53. Wang, Z.; Meng, H.; Hua, J.; Ma, Y.-J.; Yang, J.-J. The agglomeration and transferring of pan-yangtze river delta's textile industry. World Reg. Stud. 2015, 24, 123-130.

54. Sitompul, R.F.; Owen, A.D. Decomposition of Energy-Related $\mathrm{CO}_{2}$ Emissions in the Indonesian Manufacturing sector. In Proceedings of the 28th Annual IAEE International Conference, Taipei, Taiwan, 3-6 June 2005.

55. Hasanbeigi, A.; Hasanabadi, A.; Abdorrazaghi, M. Comparison analysis of energy intensity for five major sub-sectors of the textile industry in iran. J. Clean. Prod. 2012, 23, 186-194. [CrossRef]

56. Reddy, B.S.; Ray, B.K. Decomposition of energy consumption and energy intensity in indian manufacturing industries. Energy Sustain. Dev. 2010, 14, 35-47. [CrossRef]

57. Zabaniotou, A.; Andreou, K. Development of alternative energy sources for ghg emissions reduction in the textile industry by energy recovery from cotton ginning waste. J. Clean. Prod. 2010, 18, 784-790. [CrossRef]

58. Priambodo, A.; Kumar, S. Energy use and carbon dioxide emission of indonesian small and medium scale industries. Energy Convers. Manag. 2001, 42, 1335-1348. [CrossRef]

59. Bevilacqua, M.; Ciarapica, F.; Giacchetta, G.; Marchetti, B. A carbon footprint analysis in the textile supply chain. Int. J. Sustain. Eng. 2011, 4, 24-36. [CrossRef]

60. Hong, G.-B.; Su, T.-L.; Lee, J.-D.; Hsu, T.-C.; Chen, H.-W. Energy conservation potential in taiwanese textile industry. Energy Policy 2010, 38, 7048-7053. [CrossRef]

61. Lin, B.; Moubarak, M. Decomposition analysis: Change of carbon dioxide emissions in the chinese textile industry. Renew. Sustain. Energy Rev. 2013, 26, 389-396. [CrossRef]

62. Lin, B.; Ahmad, I. Analysis of energy related carbon dioxide emission and reduction potential in pakistan. J. Clean. Prod. 2017, 143, 278-287. [CrossRef]

63. Palamutcu, S. Electric energy consumption in the cotton textile processing stages. Energy 2010, 35, $2945-2952$. [CrossRef]

64. Thai, V.; Tokai, A.; Yamamoto, Y.; Nguyen, D. Eco-labeling criteria for textile products with the support of textile flows: A case study of the vietnamese textile industry. J. Sustain. Energy Environ. 2011, 2, 105-115.

65. Koenker, R.; Bassett, G., Jr. Regression quantiles. Econometrica 1978, 46, 33-50. [CrossRef]

66. Arain, H.; Han, L.; Sharif, A.; Meo, M.S. Investigating the effect of inbound tourism on fdi: The importance of quantile estimations. Tour. Econ. 2019. [CrossRef]

67. World Bank. World Development Indicators. 2020. Available online: https://data.worldbank.org/indicator/ eg.egy.prim.pp.kd (accessed on 14 April 2020).

68. Sharif, A.; Shahbaz, M.; Hille, E. The transportation-growth nexus in USA: Fresh insights from pre-post global crisis period. Transp. Res. Part. A Policy Pract. 2019, 121, 108-121. [CrossRef]

69. Mishra, S.; Sharif, A.; Khuntia, S.; Meo, S.A.; Khan, S.A.R. Does oil prices impede islamic stock indices? Fresh insights from wavelet-based quantile-on-quantile approach. Resour. Policy 2019, 62, 292-304. [CrossRef]

70. Oláh, J.; Lengyel, P.; Balogh, P.; Harangi-Rákos, M.; Popp, J. The Role of Biofuels in Food Commodity Prices Volatility and Land Use. J.Compet. 2017, 9, 81-93. [CrossRef]

71. Rybár, R.; Kudelas, D.; Beer, M. Selected problems of classification of energy sources—What are renewable energy sources? Acta Montan. Slovaca 2015, 20, 172-180.

72. Tvaronavičienè, M.; Ślusarczyk, B. Energy Transformation towards Sustainability; Elsevier: Amsterdam, The Netherlands, 2019; pp. 1-333.

(C) 2020 by the authors. Licensee MDPI, Basel, Switzerland. This article is an open access article distributed under the terms and conditions of the Creative Commons Attribution (CC BY) license (http://creativecommons.org/licenses/by/4.0/). 